\title{
Social relationships and activities following elimination of SARS-CoV-2: a qualitative cross-sectional study
}

\author{
Nicholas J. Long, ${ }^{*}$ Nayantara Sheoran Appleton, ${ }^{2}$ Sharyn Graham Davies, ${ }^{3}$ Antje Deckert, ${ }^{4}$ \\ Edmond Fehoko, ${ }^{5}$ Eleanor Holroyd, ${ }^{6}$ Nelly Martin-Anatias, ${ }^{4}$ Rogena Sterling, ${ }^{7}$ Susanna \\ Trnka, ${ }^{8}$ and Laumua Tunufa'i. ${ }^{4}$
}

\begin{abstract}
Objectives

To investigate how successfully SARS-CoV-2 elimination strategies fulfil their promise of allowing a return to a 'normal' social life, and to identify obstacles and challenges that may inhibit the realisation of this goal.

Design

Qualitative cross-sectional survey.

Setting

New Zealand community cohort.

\section{Participants}

1040 respondents entered the study (18-90 years, $\mathrm{M}=48.18 .11, \mathrm{SD}=15.52,76 \%$ women). 966 completed the questions relevant to this article. Participants were recruited via online advertisement campaigns designed to maximise variation in the sample as far as practicably possible.
\end{abstract}

\section{Main outcome measures}

Thematic analysis of participants' narratives.

\section{Results}

A majority of participants reported that the elimination of SARS-CoV-2 had allowed their life to go back to being 'more or less the same' as before the pandemic. A small number indicated the pandemic had inspired them to become more social following elimination. Nevertheless, a sizeable minority of respondents reported being less social, even many months after SARS-CoV-2 had been eliminated. This was often because of fears that the virus might be circulating undetected, or because the March-May 2020 lockdown had led to

\footnotetext{
${ }^{*}$ Corresponding author. Email: N.J.Long@1se.ac.uk

${ }^{1}$ Department of Anthropology, London School of Economics and Political Science, London, United Kingdom

${ }^{2}$ Centre for Science in Society, Victoria University of Wellington, Aotearoa New Zealand

3 School of Languages, Literatures, Cultures, and Linguistics, Monash University, Melbourne, Australia, and School of Social Sciences and Public Policy, Auckland University of Technology, Auckland, Aotearoa New Zealand

${ }^{4}$ School of Social Sciences and Public Policy, Auckland University of Technology, Auckland, Aotearoa New Zealand

5 School of Māori Studies and Pacific Studies, University of Auckland, Auckland, Aotearoa New Zealand

${ }^{6}$ School of Clinical Sciences, Auckland University of Technology, Auckland, Aotearoa New Zealand

${ }^{7}$ University of Waikato, Hamilton, Aotearoa New Zealand

${ }^{8}$ Department of Anthropology, University of Auckland, Auckland, Aotearoa New Zealand
} 
changes in relationships and personal habits that were not easily reversed. Becoming less social was associated with having an underlying health condition that heightened one's vulnerability to COVID-19 $(p=0.00005)$ and older age $(p=0.007)$.

\section{Conclusions}

Elimination strategies can successfully allow the public to return to a pre-pandemic 'normal' - or reinvent and improve their social lives should they wish. However, such outcomes are not inevitable. Re-establishing social connections after elimination can sometimes be a challenging process, with which people may need support. Plans for providing such support should be an integral part of elimination strategies.

Keywords: COVID-19; elimination; health policy; pandemic response; New Zealand; social isolation; social recovery 


\section{Introduction}

Since the onset of the COVID-19 pandemic, politicians and public health experts have disagreed over how to respond to outbreaks of SARS-CoV-2. With few prepared to let the virus spread unimpeded, debate centres on the respective merits of mitigation and elimination strategies. In mitigation, the virus continues to circulate at reduced levels, due to nonpharmaceutical interventions (NPIs), which may either be undertaken optatively by the public or legally imposed. Elimination, sometimes referred to as 'Zero-COVID' - involves the stringent deployment of NPIs with a view to reducing community spread to zero; further outbreaks are then guarded against via strict border controls, at least until appropriate vaccination thresholds are reached. ${ }^{1}$

Notwithstanding technical questions regarding the feasibility of elimination, which may prove difficult in non-OECD countries or when faced with SARS-CoV-2 strains of heightened transmissibility, proponents of each strategy are motivated by competing understandings of how best to protect the public good. Advocates of mitigation argue that the economic damage wrought by stringent lockdowns and the border closures necessary to secure Zero-COVID status would have long-term repercussions for public health. ${ }^{2}$ Supporters of elimination counter that it minimises COVID-19 fatalities and post-COVID syndrome (or 'Long COVID'), supports economic recovery by allowing businesses to resume relatively normal service and consumer confidence to return, and ultimately results in less restriction of civil liberties. ${ }^{3}$ Elimination is also seen as having social and psychological benefits, often couched in the idiom of 'normality'. ${ }^{45}$ Not only would endemic circulation of COVID-19, even at suppressed levels, entail 'profound cultural adjustment for the life of high-risk individuals in the winter months'; 6 there is, McKee argues in his critique of mitigation, 'little point in removing restrictions if a large proportion of the population is too worried to place themselves at a real or perceived risk'. ${ }^{7}$ By contrast, elimination is seen as allowing 'normal social life to resume ${ }^{8}$ and facilitating 'largely normal community life'. ${ }^{9}$ Embedded within these claims is a recognition, firstly, that the disruption of established routines is itself a psychological stressor, ${ }^{10}$ and, secondly, that the attenuated social life possible under NPIs can deprive people of much-needed social support, with potentially adverse consequences for physical health, mental health, and subjective wellbeing. ${ }^{11-13}$

To date, empirical evidence supports both the public health and economic arguments in favour of elimination. Zero-COVID strategies are associated with fewer excess deaths than mitigation, ${ }^{14-16}$ while nations that rapidly eliminated the virus have, to date, performed better economically than those in which it was suppressed. ${ }^{31718}$ However, while research shows that people living in settings adopting mitigation strategies are tending to have fewer social contacts than they did pre-pandemic after 'lockdown' restrictions have been lifted, ${ }^{19}{ }^{20}$ little is yet known about the extent to which the promise of 'normal' social and community life has been realised following the elimination of SARS-CoV-2. Quantitative analysis of the Gallup World Poll presents a mixed picture, indicating that elimination settings observed an uptick in 'prosocial activity' (making a donation, volunteering, or helping a stranger in the past month) but a reduction in reported levels of social support (whether the respondent has someone to count on in times of trouble). ${ }^{21}$ Yet such findings reveal little about the character of everyday social life or the degree to which it feels satisfying, let alone 'normal'. This study develops our understanding of elimination approaches by qualitatively analysing accounts of life in 'Zero-COVID' New Zealand (specifically, between February-August 2021), examining how successfully research participants were able to return to their pre-pandemic ways of life, and identifying specific challenges that governments adopting an elimination strategy should anticipate in future. 


\section{Methods}

\section{Theoretical orientation}

Understanding the extent to which elimination allows people to resume a satisfying, 'normal', social life requires a qualitative, social constructionist approach. As health researchers have long recognised, a sense of 'normality' principally inheres in subjective evaluations of how a practice or situation feels and how it compares to imagined baselines of 'normal' activity and behaviour. ${ }^{22} 23$ These evaluations are then expressed through narrative in a process sometimes referred to as 'narrative sense-making'. ${ }^{24}$ Moreover, such evaluations, and their narrative expression, are enacted by individuals whose expectations, understandings, and yardsticks of measurement are both constantly evolving and distinct from those held by others, even as they are to some degree co-constructed between people and within communities and are responses to shared circumstances. ${ }^{2627}$ Each narrative must thus be engaged with qualitatively, and on its own terms, whilst also remaining attentive to patterns across different cases. These goals can be achieved via the qualitative technique of thematic analysis. ${ }^{28}$

Site selection

New Zealand is an ideal site in which to investigate social life following the elimination of SARS-CoV-2. The New Zealand government has highlighted 'get[ting] back to a sense of normality' as a reason to pursue its elimination strategy, ${ }^{29}$ and the country is frequently assumed to have enjoyed 'normal' social and community life following the elimination. ${ }^{89}$ Indeed, this is one reason for New Zealand to be widely regarded as a poster child for ZeroCOVID approaches.

Elimination first occurred in May 2020, following a 49-day national lockdown, ${ }^{30} 31$ and on 8 June 2020 the whole of the country moved to 'Alert Level 1', in which activities were permitted to operate without restriction - although enhanced record-keeping was recommended, and mask-wearing on public transport mandated. Small community outbreaks in August 2020 and February 2021 led to short periods of enhanced restriction, mostly in the city of Auckland. Nevertheless, until the incursion of the Delta variant triggered a further nationwide lockdown in August 2021, New Zealand had enjoyed many months of freedom from COVID-19 restrictions (see Figures 1 and 2). Vaccine rollout began during this time, with frontline workers vaccinated from February 2021 and members of the public vaccinated from May 2021. However, the pace of rollout has been slow, with only $18 \%$ of the population fully vaccinated and 29\% having received one dose by the start of August $2021 .^{32}$ For most people, the elimination strategy has been the principal line of defence since the pandemic began.

Figure 1. COVID Alert Levels in Auckland between 21st March 2020 and 31st August 2021.

Figure 2. COVID Alert Levels in most parts of New Zealand other than Auckland between 21 st March 2020 and 31st August 2021. N.B. Wellington was also at Alert Level 2 for six days between 23 and 29 June 2021.

\section{Participants}

This research was envisaged as a qualitative study. It did not seek to provide a statistically representative account. Rather, following Cole and Knowles' argument that every 
'exploration of an individual life-in-context brings us that much closer to understanding the complexities of lives in communities', ${ }^{33}$ it investigated the range of possible experiences that people could have following New Zealand's re-opening, using respondents' own words to identify key dynamics underpinning different behavioural pathways. Sampling aimed to maximise variation as far as practicably possible, so we could trace contrasts and patterns within the data obtained. ${ }^{34}$ It continued until we observed saturation in the data.

Recognising the flexibility, scalability, and richness of online surveys as a method of gathering qualitative data, ${ }^{35}$ we advertised an online research survey via nationwide Facebook and Instagram campaigns, including bespoke campaigns targeted at men and younger age groups, to heighten variation within the sample. Participants were also recruited from a database of contacts who had participated in the research team's previous surveys on experiences of the COVID-19 pandemic in New Zealand - who were themselves recruited via advertising campaigns intended to maximise variation. ${ }^{3637}$ The survey was selfadministered and thus unlikely to have been influenced by researcher characteristics. In total, the survey received 1040 valid responses. The respondent pool showed good variation in terms of age and region of residence but, despite our attempts to maximise variation, and as is often the case with survey research in New Zealand, ${ }^{38}$ contained disproportionate numbers of women, New Zealand European / Pākehā people, and university graduates.

Survey design

We distributed the online survey between $18^{\text {th }}$ August and 25 ${ }^{\text {th }}$ August 2021, canvassing respondents' opinions on various aspects of New Zealand's pandemic response, and assessments of how their lives over the previous six months (including domestic and neighbourhood relations, friendships, social life, working practices and outlook on life) compared to their lives before the pandemic (see Supplementary Annex for a full schedule of questions). Respondents could indicate that these were 'more or less the same', 'a little different' or 'extremely different' and were then prompted to explain their answer in their own words. 966 respondents answered the question about how much their social lives had changed. 494 provided narrative elaborations.

\section{Analysis}

Having anonymised and read these narrative answers multiple times, two researchers (NJL and SGD) independently coded them for analysis under both anticipated themes (e.g., whether they described upturns, downturns or continuity in the quality and quantity of social relationships and activities) and emergent themes discovered through exploring the data (e.g., references to relationships with people overseas, increased use of technology, and epidemiological considerations). ${ }^{39}$ Independent coding helped to ensure trustworthiness. Disagreements over codes were resolved via consensus discussion. We used constant comparison to ensure that our thematic analysis provided a comprehensive overview of themes and subthemes evident in the data..$^{4041}$

Our coding strategy allowed us to conduct a statistical exploration of patterns in the data. ${ }^{42}$ Using Microsoft Excel v.16.52, we conducted Chi-squared tests for independence to examine the frequency of three key themes - 'returning to normal' (code N), 'becoming more social' (code P), and 'becoming less social' (code L) - across five demographic variables: gender, age, ethnicity, education status, household size, and presence or absence of underlying health conditions that might affect one's vulnerability to COVID-19. In cases where responses had received multiple codes, we identified a single 'predominant' code for the purposes of statistical analysis, since the Chi-square test requires independent observations. Recognising that respondents may have been less likely to elaborate on an answer indicating that their lives were 'more or less the same' than when having reported a 
difference, separate tests were run for associations between the prevalence of $\mathrm{P}$ and $\mathrm{L}$ codes not only vis-à-vis $\mathrm{N}$ codes but also vis-à-vis $\mathrm{N}$ codes and unelaborated 'more or less the same' answers. Since respondents had been able to select multiple ethnic labels, the tests for ethnicity were based on concatenations of the data: we ran separate tests to see whether there were any associations between survey responses and identifying exclusively as White (whether by checking the 'New Zealand European / Pākehā' box, or reporting another Caucasian ethnicity under 'Other') or identifying non-exclusively as Māori. We also tested to see whether there was any association with being Māori or Pacific, since these two groups have been identified as especially vulnerable to COVID-19. ${ }^{43}$ Small cell sizes precluded tests for associations with other ethnicity options in the survey.

Patient and public involvement

Neither patients nor the public were involved in the design or conduct of this research.

\section{Results}

Thematic analysis revealed three overarching patterns of social behaviour in the wake of elimination. The most common response was that life was 'more or less the same' as it had been before the pandemic. However, a minority of our sample reported having become more social, and an even more sizeable minority reported having become less social. These responses varied by gender and age, but also, and most dramatically, by health status, indicating that those who are most vulnerable to COVID-19 may also be least able to achieve social recovery once SARS-CoV-2 has been eliminated.

\section{Returning to the pre-pandemic 'normal'}

Of the 966 respondents who answered the question about friendships and social life, 531 indicated that these had been 'more or less the same' over the previous six months (i.e. from February - August 2021) as they had before the pandemic. When elaborating on their answers, most of these respondents attested that nothing had changed (Table 1 - Quote 1). They described Level 1 as allowing a return to normality (Quote 2), and feeling grateful and 'lucky' that the New Zealand government had adopted an elimination strategy (Quotes 3 and 4). Some explained that the social gains of life at Levels 1 and 2 justified the 'sacrifice' of lockdowns (Quote 5). Several mentioned that elimination had allowed them to feel 'safe' (Quotes 3 and 6) alleviating their feelings of 'fear' (Quote 7). One respondent, who had spent three months of 2021 in the United Kingdom - a country which has adopted a mitigation strategy - contrasted the 'normality' of Zero-COVID with the 'frightening' feeling of socialising post-lockdown in the UK (Quote 8). Only in a handful of cases was the 'normality' of social life linked to a wilful blindness towards the pandemic (Quote 9). Interestingly, although most respondents were supportive of the vaccination programme elsewhere in the survey, none mentioned it as a factor contributing to their experience of social recovery.

11 respondents, including a few who indicated that their social life and friendships had become 'a little different', described minor changes resulting from heightened awareness of health and hygiene, as opposed to substantive shifts in the frequency or character of social activity (Quotes 10 and 11). Nevertheless, several reports of a 'return to normality' were haunted by a sense of contingency, with respondents indicating that life might have been less normal if they had friends who were border workers (Quote 12), or if they were less adept at handling differences of opinion within their relationships (Quote 13). This indicates a recognition that the post-elimination context may put pressures on certain relationships. 


\section{Table 1. Returning to pre-pandemic normality.}

\section{Becoming more social}

95 respondents shared narratives describing an intensification of social activities following the elimination of COVID-19. Some framed this as a response to the lockdown, couched in the idiom of 'making up for lost time' (Table 2 - Quote 1), while other respondents explained that the pandemic had revealed the fragility of social freedoms they had previously taken for granted (Quote 2), and, indeed, human life (Quote 3), inspiring them to prioritise friendships and social activities more than they previously had (Quotes 4 and 5), and to appreciate their loved ones more (Quote 6).

In several cases, the experience of being 'locked down' in 2020 had afforded opportunities for new friendships to be made - especially with those in the local community (Quote 7) - and these new intimacies had persisted into the post-elimination period. Others noted that the challenges of the pandemic had allowed them to forge closer relationships with others, by allowing them to be more honest about their emotions (Quote 8), or by rendering friendships more 'meaningful' (Quote 9).

\section{Table 2. Becoming more social}

\section{Becoming less social}

253 respondents gave qualitative answers in which life in a Zero-COVID New Zealand was associated with a decline in the quantity or quality of social relationships. In 24 cases, this was explicitly linked to the border closures integral to the elimination strategy (Table 3 Quote 1). The majority described their social lives and social networks within New Zealand having changed since pre-pandemic times. They often reported changes in activities ('socialising less' or spending less time in public places - Quotes 2 and 3), changes in character (becoming 'less social' - Quote 4), and an overall sense of their world 'having shrunk' (Quote 5).

For some respondents, these changes were linked to an ongoing fear that SARS-CoV2 might have entered New Zealand and be in circulation, despite announcements that community transmission had been eliminated. They worried that, by socialising, they might either contract it (Quote 6) or pass it to others (Quote 7). Others described how the anxiety and stress that they had experienced due to the pandemic had triggered feelings of depression, that then impeded them from undertaking social activities that they might otherwise want to (Quote 8). Such anxieties could have knock-on consequences, with a diminished social life activity sometimes arising from frequent cancellations (Quote 9).

In other cases, the change in social patterns was presented as a consequence of having lived through the seven-week lockdown in March-May 2020. Some respondents described ongoing 'lockdown fatigue' (Quote 10), while others explained how the lockdown had 'habituated' them to staying at home (Quote 11). Some friendships had been strained during the lockdown period due to disagreements over the meaning or importance of lockdown rules (Quote 12), while other respondents felt that the lockdown had led people to "withdraw into family life' at the expense of their friendships (Quote 13). Both of these dynamics were also reported as having arisen even after lockdown had ended: disagreements over vaccine uptake or the government's COVID response had caused some people to sever ties with certain friends (Quote 14), while those whose friends had a propensity to 'stay at home' - for 
whatever reason - noted that those friendships now felt thinner, with less to talk about (Quote $15)$.

Not all respondents viewed these changes in their social lives as negative. Some appreciated being able to focus only on their 'most important' relationships (Quotes 3 and 16), the 'deep' conversation afforded by smaller gatherings (Quote 17), or being able to 'indulge their introvert side' (Quote 18). For others, however, the loss of connection had led to a heightened sense of isolation (Quote 19) and deteriorating mental health (Quote 20).

\section{Table 3. Becoming less social}

\section{Response Distribution}

The three patterns described above could be observed amongst respondents of all backgrounds. Statistical analysis of the prevalence of codes indicating 'becoming more social' or 'becoming less social' relative to codes or answers indicating a return to prepandemic normality (Table 4) did not indicate any significant associations with ethnicity, education status or residence size. There were, however, statistically significant associations with health status and age. Respondents with underlying conditions were more likely to have become less social and less likely to have become more social than those who did not $(p=$ $0.00005)$. Similarly, those in younger age brackets were more likely to be pro-social, and those in older age brackets more likely to be less social $(p=0.009)$ - although this pattern may partly reflect the increased prevalence of underlying health conditions in older age groups. Analysis also revealed a statistically significant association with gender: women were more likely to report having become more social or having become less social, and men more likely to report continuity ( $p=0.007)$. This finding may reflect gendered differences in behavioural pathways following elimination, but may also reflect longstanding gender roles in Western societies, in which women have often been deemed responsible for thinking about and managing social relationships, ${ }^{44-46}$ and thus potentially more inclined to detect and report changes in their social networks.

\section{Table 4: Distribution of responses to question about changes to friendships and social life}

\section{Discussion}

Elimination strategies can indeed allow many people to regain a sense of 'normality' within their social lives, even inspiring them to adopt modes of sociality they considered better than those they had experienced before. Such positive outcomes, however, are far from inevitable. Many respondents reported lower levels of social contact after the virus had been eliminated than before the pandemic. This was especially, but not only, the case for older respondents and those with underlying health conditions.

While the thematic analysis allowed us to identify three distinct patterns of response to elimination, and key factors that influenced each of those responses, we cannot be certain how well the prevalence of those responses within our sample reflects their prevalence amongst New Zealand's public. Given the high proportion of respondents identifying as women (76.6\%) and reporting underlying health conditions (31.7\%), and a mean age above the national average, it seems likely that the pathway of 'becoming less social' is overrepresented in our results. Although a statistically representative study would better delineate the scale of the challenges, this qualitative study nevertheless identifies several 
distinct dynamics that can obstruct 'returning to normality', showing a clear need for policy measures and messaging that can support the public in their transition to post-elimination life.

Retrospective self-reporting is sometimes considered inferior to observational studies. ${ }^{47}$ We see the retrospective nature of our survey as a strength, since it allows us to better understand the narrative sense-making undertaken by our respondents. Nevertheless, the cross-sectional nature of the study meant such narrativisation was occurring at a specific moment in time: by happenstance, community outbreaks of the Delta variant led to New Zealand entering Level 4 lockdown just as our survey was due to be launched. The sense of pessimism surrounding the lockdown may have led some respondents to exaggerate what had been lost since before the pandemic, and others to romanticise life immediately prior to lockdown - although a strength of this timing was that it allowed respondents to reflect back on the longest possible sustained period at Level 1. Our study thus complements existing studies on social attitudes and behaviours in the immediate aftermath of the 2020 lockdown, and shows how many of the trends reported in that research, including an aversion to mixing with strangers, ${ }^{48}$ ongoing uncertainty about the trajectory of the pandemic, ${ }^{49}$ and worsening mental health, ${ }^{51}$ appear to have persisted for many months, despite minimal domestic COVID-19 cases. It also goes beyond those studies by offering a more integrated understanding of how respondents are experiencing and evaluating their social life, engaging with respondents' accounts of the pandemic on their own terms, and identifying age and medical vulnerability to COVID-19 as risk factors for social disconnection.

As our thematic analysis reveals, the shrinkage of a social network is not always undesirable: it need not equate to 'loneliness', and may even be experienced as a relief. Nevertheless, research in New Zealand ${ }^{52-55}$ and beyond ${ }^{56-58}$ points to strong correlations between the number and quality of social relationships and overall physical and mental health. There are also known psychological benefits associated with living in a world that feels 'normal'. ${ }^{10}$ Enabling people to restore or expand their pre-pandemic social networks is thus not only a sociocultural prerogative, but also a public health imperative. ${ }^{59}$

Elimination strategies would hence be improved by anticipating and mitigating against common obstacles to people taking full advantage of the opportunities afforded by a Zero-COVID environment. Foremost is the ongoing fear of contagion, which is not necessarily eliminated with the virus - especially when a pandemic continues to rage internationally. In addressing such fear, policy makers must strike a delicate balance between maintaining appropriate levels of caution (e.g., via diligent use of contact tracing, etc.) and encouraging people to take advantage of their hard-won freedoms. Public health messaging should champion adjustments made to make public venues as COVID-secure as possible (for example, by increasing airflow), promote low-risk ways in which one can gather with friends (such as by meeting outdoors), and emphasise that reconnecting with others is a public health good in its own right, perhaps harnessing the tropes of 'kindness' and 'togetherness' that underpinned New Zealand's initial messaging around lockdown. ${ }^{60}$

Our study also demonstrates how even a relatively short (49 day) lockdown, especially one of the stringency required to achieve elimination, can have long-term impacts on personal habits, relationships, and mental health - all of which can affect social networks. Funding of mental health services - including both individual psychotherapies and systemic psychotherapies where patients can work through the schisms that have arisen in their relationships - should thus be increased as a matter of priority; indeed, in New Zealand there has been an urgent need for increased funding and service reform since well before the pandemic. ${ }^{61}$ Healthcare providers could encourage volunteering ${ }^{62} 63$ and other forms of social prescribing. ${ }^{64}{ }^{65}$ Public health messaging should highlight the value of repairing interpersonal tensions that arose during lockdown, disseminate advice on how to protect relationships from potentially destructive differences of opinion, and openly acknowledge that 'returning to 
normal' following the challenges of both lockdowns and a global pandemic may need to be undertaken consciously and effortfully, rather than occurring automatically.

Future research in New Zealand should focus on perspectives of people that were not fully captured within our dataset (for example, our study design precluded us from accessing the experiences of under-18s, those too economically disadvantaged to have internet access, and non-English speakers), and the extent to which vaccine rollout can support social recovery. More research is also needed on Māori and Pacific experiences, given the relatively small numbers participating in the survey, the long-standing structural inequities and, relatedly, health disparities affecting these groups, and their disproportionate vulnerability to COVID-19. ${ }^{4366-69}$ Investigating whether comparable patterns are observed in settings that have achieved elimination in different ways - such as Taiwan, which used a sophisticated contact tracing system rather than lockdowns ${ }^{70}$ - would usefully inform decisions over what kind of elimination strategy governments should aspire to in their pandemic planning.

\section{Conclusion}

Where possible - and recognising that the capacity to do so may be limited by the resources available to any given nation-state, as well as by the pathogen's epidemiology - nations should consider elimination strategies of pandemic response on the grounds that they can enable social recovery, as well as guarding against excess mortality and limiting economic damage. Nevertheless, pandemic planning must anticipate the challenges that certain members of the public might encounter in transitioning back to a satisfying life, especially if elimination requires a period of lockdown or sheltering in place. It is imperative to recognise that pandemic control measures can strain social relationships in various ways, and to furnish populations with resources that can help to resolve such difficulties. Clear guidance on how to socialise safely, and the importance of doing so, is also crucial to ensure concerned members of the public can safeguard their access to social support and thereby protect their own, and others', physical and mental health.

\section{Summary Box}

\section{What is already known on this topic}

- Elimination strategies have attracted widespread support for their capacity to allow 'normal' social and community life to resume.

- There is a paucity of data on how people have been experiencing life in settings where SARS-CoV-2 has been eliminated.

What this study adds

- Our study shows that while the elimination of SARS-CoV-2 has allowed many people to return to a 'normal' social life, such a return is far from inevitable.

- Older people and people with underlying health conditions are especially likely to report becoming less social since the pandemic began, despite the elimination of SARSCoV-2.

- Elimination strategies should include measures specifically designed to encourage social re-connection. 


\section{Ethics statements}

\section{Patient Consent for Publication}

Not required

Ethics approval

Ethical approval was provided by the Research Ethics Committee at the London School of Economics and Political Science (ref 11.08c). All respondents were provided with study information before beginning the survey and asked to indicate their consent.

\section{Data availability statement}

Data underlying the results reported in this article will be available, after deidentification, from the corresponding author upon reasonable request, beginning three months and ending five years following article publication.

\section{Footnotes}

\section{Contributors}

NJL, NSA, SGD, AD, EF, EH, NMA, RS, and LT conceived and designed the study. NJL and SGD conducted the coding. All authors contributed to the interpretation of data. NJL conducted the statistical analysis and wrote the first draft. All authors revised the manuscript for intellectual content. Though not involved in designing this study, Pounamu Jade Aikman and Michael Roguski provided valuable input on how to present issues pertaining to ethnicity in the final draft. The corresponding author attests that all listed authors meet authorship criteria and that no others meeting the criteria have been omitted. NJL is guarantor.

\section{Funding}

The cost of administering the surveys was supported by NJL's annual London School of Economics and Political Science Staff Research Fund. No external funding was received. All authors had full access to all of the data (including statistical reports and tables) and can take responsibility for the integrity of the data and the accuracy of the data analysis.

\section{Competing interests}

All authors have completed the ICMJE uniform disclosure form and declare: no support from any organisation for the submitted work; and no financial relationships with any organisations that might have an interest in the submitted work in the previous three years. RS is Chairperson of Intersex Trust Aotearoa New Zealand and a board member of Pacific Women's Watch. LT sits on the Board of Trustees of Koru School, Favona, Auckland. There are no other relationships or activities to declare that could appear to have influenced the submitted work.

\section{Transparency statement}

The lead author (NJL) affirms that the manuscript is an honest, accurate, and transparent account of the study being reported; that no important aspects of the study have been omitted; and that any discrepancies from the study as planned (and, if relevant, registered) have been explained. 
Dissemination to participants and related patient and public communities

There are plans to disseminate the results of the research to the general public, primarily through media outreach (e.g., press releases by the research institutions of the contributing authors, and plain language publications in popular and social media). Findings will also be communicated to participants who provided us with a contact email address.

\section{References}

1. Baker MG, Wilson N, Blakely T. Elimination could be the optimal response strategy for covid-19 and other emerging pandemic diseases. BMJ 2020;371:m4907. doi: https://doi.org/10.1136/bmj.m4907

2. Lee A, Thornley S, Morris AJ, et al. Head To Head: Should countries aim for elimination in the covid-19 pandemic? BMJ 2020;370:m.3410. doi: https://doi.org/10.1136/bmj.m3410

3. Oliu-Barton M, Pradelski BSR, Aghion P, et al. SARS-CoV-2 elimination, not mitigation, creates best outcomes for health, the economy, and civil liberties. The Lancet 2021;397(10291):2234-36. doi: https://doi.org/10.1016/S0140-6736(21)00978-8

4. Independent SAGE. A Better Way To Go: towards to a Zero COVID UK: https://www.independentsage.org/wp-content/uploads/2020/07/20200717-A-BetterWay-To-Go.pdf, 2020.

5. Abi-Rached JM, Issa N, Khalife J, et al. Towards a Zero-COVID Lebanon: A Call for Action. Paris: Arab Reform Initiative, 2020.

6. Murray CJL, Piot P. The Potential Future of the COVID-19 Pandemic: Will SARS-CoV-2 Become a Recurrent Seasonal Infection? JAMA 2021;325(13):1249-50. doi: 10.1001/jama.2021.2828

7. McKee M. Achieving zero covid is not easy, but the alternative is far worse. $B M J$ 2020;371:m.3859. doi: https://doi.org/10.1136/bmj.m3859

8. Ryan T. Time to embrace zero-Covid policy. Irish Times 22 August 2020; https://www.irishtimes.com/opinion/time-to-embrace-zero-covid-policy-1.4335769.

9. Skegg DC, Hill PC. Defining covid-19 elimination. BMJ 2021;374:n.1794. doi: https://doi.org/10.1136/bmj.n1794

10. Blake D. Preparedness and Recovery as a Privilege in the Context of Covid-19. Auckland: Economic and Social Research Aotearoa. https://esra.nz/preparednessrecovery-privilege-context-covid-19/, 2020.

11. Long NJ. From social distancing to social containment: reimagining sociality for the coronavirus pandemic. Medicine Anthropology Theory 2020;7(2):247-60. doi: https://doi.org/10.17157/mat.7.2.791

12. Tull MT, Edmonds KA, Scamaldo KM, et al. Psychological Outcomes Associated with Stay-at-Home Orders and the Perceived Impact of COVID-19 on Daily Life. Psychiatry Research 2020;289:113098. doi: 10.1016/j.psychres.2020.113098

13. Kilgore WDS, Cloonan SA, Taylor EC, et al. Loneliness during the first half-year of COVID-19 Lockdowns. Psychiatry Research 2020;294:113551.

14. Karlinsky A, Kobak D. Tracking excess mortality across countries during the COVID-19 pandemic with the World Mortality Dataset. eLife 2021;10:e69336. doi: 10.7554/eLife.69336 
15. Islam N, Shkolnikov VM, Rolando J Acosta, et al. Excess deaths associated with covid19 pandemic in 2020: age and sex disaggregated time series analysis in 29 high income countries. BMJ 2021;373:n1137. doi: https://doi.org/10.1136/bmj.n1137

16. Kung S, Doppen M, Black M, et al. Reduced mortality in New Zealand during the COVID-19 pandemic. The Lancet 2020;397(10268):P25. doi: https://doi.org/10.1016/S0140-6736(20)32647-7

17. Patel J, Sridhar D. We should learn from the Asia-Pacific responses to COVID-19. The Lancet Regional Health - Western Pacific 2020;5:100062. doi: https://doi.org/10.1016/j.lanwpc.2020.100062

18. Menon P. NZ economy surges as housing, retail drive post-COVID recovery. Reuters 17 June 2021; https://www.reuters.com/world/asia-pacific/nz-economy-surges-housingretail-drive-post-covid-recovery-2021-06-16/.

19. Liu CY, Berlin J, Kiti MC, et al. Rapid review of social contact patterns during the COVID-19 pandemic. Epidemiology 2021 doi: 10.1097/EDE.0000000000001412

20. Coletti P, Wambua J, Gimma A, et al. CoMix: comparing mixing patterns in the Belgian population during and after lockdown. Scientific Reports 2020;10:21885. doi: https://doi.org/10.1038/s41598-020-78540-7

21. Helliwell JF, Norton MB, Wang S, et al. Well-being analysis favours a virus-elimination strategy for COVID-19. Working Paper 29092. Cambridge, MA: National Bureau of Economic Research, 2021.

22. Boaz A, Morgan M. Working to establish 'normality' post-transplant: A qualitative study of kidney transplant patients. Chronic Illness 2014;10(4):247-58. doi: https://doi.org/10.1177/1742395313504789

23. Waldron R, Malpus Z, Shearing V, et al. Illness, normality and identity: the experience of heart transplant as a young adult. Disability and rehabilitation 2017;37(19):1976-82. doi: https://doi.org/10.1080/09638288.2016.1213896

24. Horstman HK, Maliski R, Hays A, et al. Unfolding narrative meaning over time: The contributions of mother-daughter conversations of difficulty on daughter narrative sense-making and well-being. Communication Monographs 2016;83(3):326-48. doi: https://doi.org/10.1080/03637751.2015.1068945

25. Jensen AN, Bonnén KB, Kristiansen M. "We don't talk about his heart": Narrative sensemaking and long-term readjustment among older out-of-hospital cardiac arrest survivors and their spouses. Resuscitation Plus 2020;3:100024. doi: https://doi.org/10.1016/j.resplu.2020.100024

26. Genuis SK, Bronstein J. Looking for "Normal": Sense Making in the Context of Health Disruption. Journal of the Association for Information Science and Technology 2017;68(3):750-61. doi: https://doi.org/10.1002/asi.23715

27. Bezmez D, Shakespeare T, Lee K. Theorising rehabilitation: Actors and parameters shaping normality, liminality and depersonalisation in a UK hospital. Sociology of Health and Illness 2021;43(3):713-31. doi: https://doi.org/10.1111/1467-9566.13252

28. Kiger ME, Varpio L. Thematic analysis of qualitative data: AMEE Guide No. 131. Medical Teacher 2020;42(8):846-50. doi: https://doi.org/10.1080/0142159X.2020.1755030

29. McClure T. New Zealand won't 'throw in towel' on Covid-zero strategy despite rising infections. The Guardian 25 August 2021; https://www.theguardian.com/world/2021/aug/25/new-zealand-wont-throw-in-towelon-covid-zero-strategy-despite-rising-infections.

30. Cousins S. New Zealand eliminates COVID-19. The Lancet 2020;395(10235):1474. doi: https://doi.org/10.1016/S0140-6736(20)31097-7 
31. Jefferies S, French N, Gilkison C, et al. COVID-19 in New Zealand and the impact of the national response: a descriptive epidemiological study. Lancet Public Health 2020;5:e612-23. doi: https://doi.org/10.1016/S2468-2667(20)30225-5

32. McClure T. Ardern's popularity stumbles on New Zealand's slow road to vaccination. The Guardian 4 August 2021; https://www.theguardian.com/world/2021/aug/04/ardern-labour-popularity-stumbleson-new-zealand-slow-road-to-vaccination

33. Cole AL, Knowles JG. Lives in context: the art of life history research. Lanham: AltaMira Press, 2001.

34. Emmel N. Sampling and Choosing Cases in Qualitative Research: A Realist Approach. Thousand Oaks, CA: SAGE, 2013.

35. Braun V, Clarke V, Boulton E, et al. The online survey as a qualitative research tool. International Journal of Social Research Methodology 2020 doi: https://doi.org/10.1080/13645579.2020.1805550

36. Long NJ. Lockdown Anthropology and Online Surveys: Unprecedented Methods for Unprecedented Times. Studies in Indian Politics 2020;8(2):294-97. doi: doi.org/10.1177/2321023020963839

37. Trnka S, Long NJ, Aikman PJ, et al. Negotiating Risks and Responsibilities during Lockdown: Ethical Reasoning and Affective Experience in Aotearoa New Zealand. Journal of the Royal Society of New Zealand 2021;51(S1):S55-S74. doi: https://doi.org/10.1080/03036758.2020.1865417

38. Houkamau CA, Sibley CG. The role of culture and identity for economic values: a quantitative study of Māori attitudes. Journal of the Royal Society of New Zealand 2019;49(S1):119-36. doi: https://doi.org/10.1080/03036758.2019.1650782

39. Pope C, Ziebland S, Mays N. Analysing qualitative data. BMJ 2000;320:114. doi: https://doi.org/10.1136/bmj.320.7227.114

40. Tuckett AG. Applying thematic analysis theory to practice: A researcher's experience. Contemporary Nurse 2005;19(1-2):75-87. doi: https://doi.org/10.5172/conu.19.1-2.75

41. Corbin J, Strauss A. Basics of Qualitative Research: Techniques and Procedures for Developing Grounded Theory. 4th edition. Los Angeles: SAGE, 2014.

42. Joffe H, Yardley L. Content and thematic analysis. In: Marks DF, Yardley L, eds. Research Methods for Clinical and Health Psychology. London: SAGE, 2004:56-69.

43. Steyn N, Binny RN, Hannah K, et al. Māori and Pacific people in New Zealand have a higher risk of hospitalisation for COVID-19. New Zealand Medical Journal 2021;134(1538):28-43.

44. Czymara CS, Langenkamp A, Cano T. Cause for concerns: gender inequality in experiencing the COVID-19 lockdown in Germany. European Societies 2020;23(sup1):S68-S81. doi: https://doi.org/10.1080/14616696.2020.1808692

45. Eichenbaum L, Orbach S. Outside in...Inside out. Women's psychology: a feminist psychoanalytic perspective. London: Penguin, 1982.

46. Morini C. The Feminization of Labour in Cognitive Capitalism. Feminist Review 2007;87(1):40-59. doi: https://doi.org/10.1057/palgrave.fr.9400367

47. Gram M. Self-reporting vs. observation: some cautionary examples from parent/child food shopping behaviour. International Journal of Consumer Studies 2010;34(4):39499. doi: https://doi.org/10.1111/j.1470-6431.2010.00879.x

48. Thaker J, Menon V. Aotearoa-New Zealand Public Responses to COVID-19. Palmerston North: Massey University, 2020.

49. Jones A. Finding the Positives From COVID-19 Within the "New Normal". New Zealand Journal of Physiotherapy 2020;48(3):105-06. doi: https://doi.org/10.15619/NZJP/48.3.01 
50. Goodyear-Smith F, Bui N, Eggleton K. Quick COVID-19 New Zealand Primary Care Survey, series 1-4. Annals of Family Medicine, COVID-19 Collection 2021 doi: https://dx.doi.org/10.7302/386

51. Gasteiger N, Vedhara K, Massey A, et al. Depression, anxiety and stress during the COVID-19 pandemic: results from a New Zealand cohort study on mental well-being. BMJ Open 2021;11:e045325. doi: 10.1136/bmjopen-2020-045325

52. Romans SE, Walton VA, Herbison GP, et al. Social Networks and Psychiatric Morbidity in New Zealand Women. Australian and New Zealand Journal of Psychiatry 1992;26(3):485-92. doi: 10.3109/00048679209072075

53. Wright-St Clair V, Neville S, Forsyth V, et al. Integrative review of older adult loneliness and social isolation in Aotearoa/New Zealand. Australasian Journal on Ageing 2017;36(2):114-23. doi: https://doi.org/10.1111/ajag.12379

54. Saeri AK, Cruwys T, Barlow FK, et al. Social connectedness improves public mental health: Investigating bidirectional relationships in the New Zealand attitudes and values survey. Australian and New Zealand Journal of Psychiatry 2018;52(4):365-74. doi: https://doi.org/10.1177/0004867417723990

55. Lay-Yee R, Campbell D, Milne B. Social attitudes and activities associated with loneliness: Findings from a New Zealand national survey of the adult population. Health and Social Care in the Community 2021 doi: https://doi.org/10.1111/hsc.13351

56. Flaskerud JH. Loneliness, Social Isolation, Morbidity and Social Networks. Issues in Mental Health Nursing 2020;41(7):650-54. doi: https://doi.org/10.1080/01612840.2019.1705947

57. Pai N, Vella S-L. COVID-19 and loneliness: A rapid systematic review. Australian and New Zealand Journal of Psychiatry 2021 doi: https://doi.org/10.1177/00048674211031489

58. Rook KS, Charles ST. Close social ties and health in later life: Strengths and vulnerabilities. American Psychologist 2017;72(6):567-77. doi: https://doi.org/10.1037/amp0000104

59. Umberson D, Montez JK. Social Relationships and Health: A Flashpoint for Health Policy. Journal of Health and Social Behavior 2010;51(Suppl):S54-S66. doi: 10.1177/0022146510383501

60. Long NJ, Aikman PJ, Appleton NS, et al. Living in bubbles during the coronavirus pandemic: insights from New Zealand 2020 [Available from: http://eprints.lse.ac.uk/104421/.

61. Paterson R, Durie M, Disley B, et al. He Ara Oranga: Report of the Government Inquiry into Mental Health and Addiction. Wellington: Government Inquiry into Mental Health and Addiction, 2018.

62. Vannier C, Mulligan H, Wilkinson A, et al. Strengthening community connection and personal well-being through volunteering in New Zealand. Health and Social Care in the Community 2021 doi: https://doi.org/10.1111/hsc.13340

63. Tierney S, Mahtani KR, Wong G, et al. The role of volunteering in supporting well-being - What might this mean for social prescribing? A best-fit framework synthesis of qualitative research. Health and Social Care in the Community 2021 doi: https://doi.org/10.1111/hsc.13516

64. Islam MM. Social Prescribing-An Effort to Apply a Common Knowledge: Impelling Forces and Challenges. Frontiers in Public Health 2020;8:515469. doi: 10.3389/fpubh.2020.515469

65. Drinkwater C, Wildman J, Moffatt S. Social prescribing. BMJ 2019;364:11285. doi: https://doi.org/10.1136/bmj.11285 
66. Reid J, Taylor-Moore K, Varona G. Towards a Social-Structural Model for Understanding Current Disparities in Maori Health and Well-Being. Journal of Loss and Trauma 2014;19(6):514-36. doi: https://doi.org/10.1080/15325024.2013.809295

67. O'Connor T. Outlining Pacific health disparities. Kai Tiaki: Nursing New Zealand 2018;24(5):23.

68. Moewaka Barnes H, McCreanor T. Colonisation, hauora and whenua in Aotearoa. Journal of the Royal Society of New Zealand 2019;49(sup1):19-33. doi: https://doi.org/10.1080/03036758.2019.1668439

69. Marriott L, Alinaghi N. Closing the Gaps: An Update on Indicators of Inequality for Māori and Pacific People. Journal of New Zealand Studies 2021;NS32:2-39. doi: https://doi.org/10.26686/jnzs.iNS32.6863

70. Summers J, Cheng H-Y, Lin H-H, et al. Potential lessons from the Taiwan and New Zealand health responses to the COVID-19 pandemic. The Lancet Regional Health Western Pacific 2020;4:100044. doi: https://doi.org/10.1016/j.lanwpc.2020.100044 


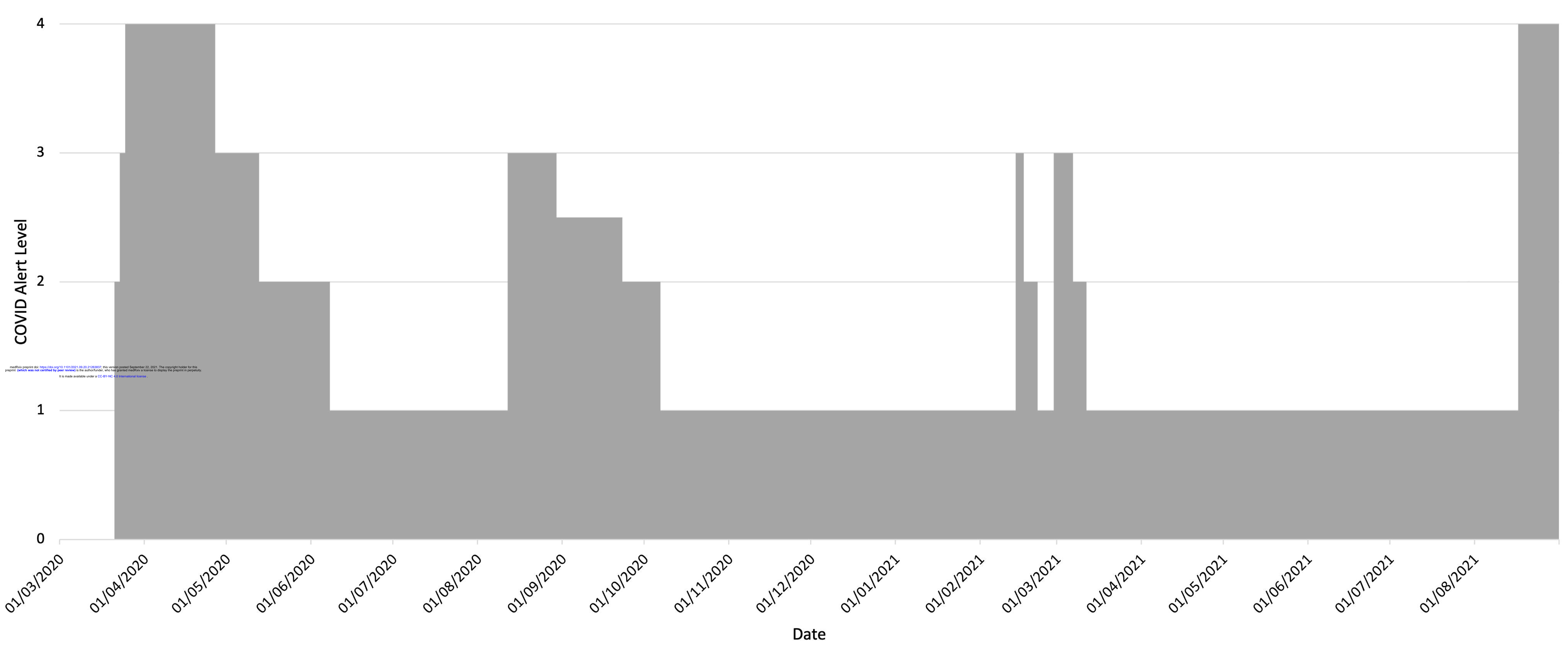




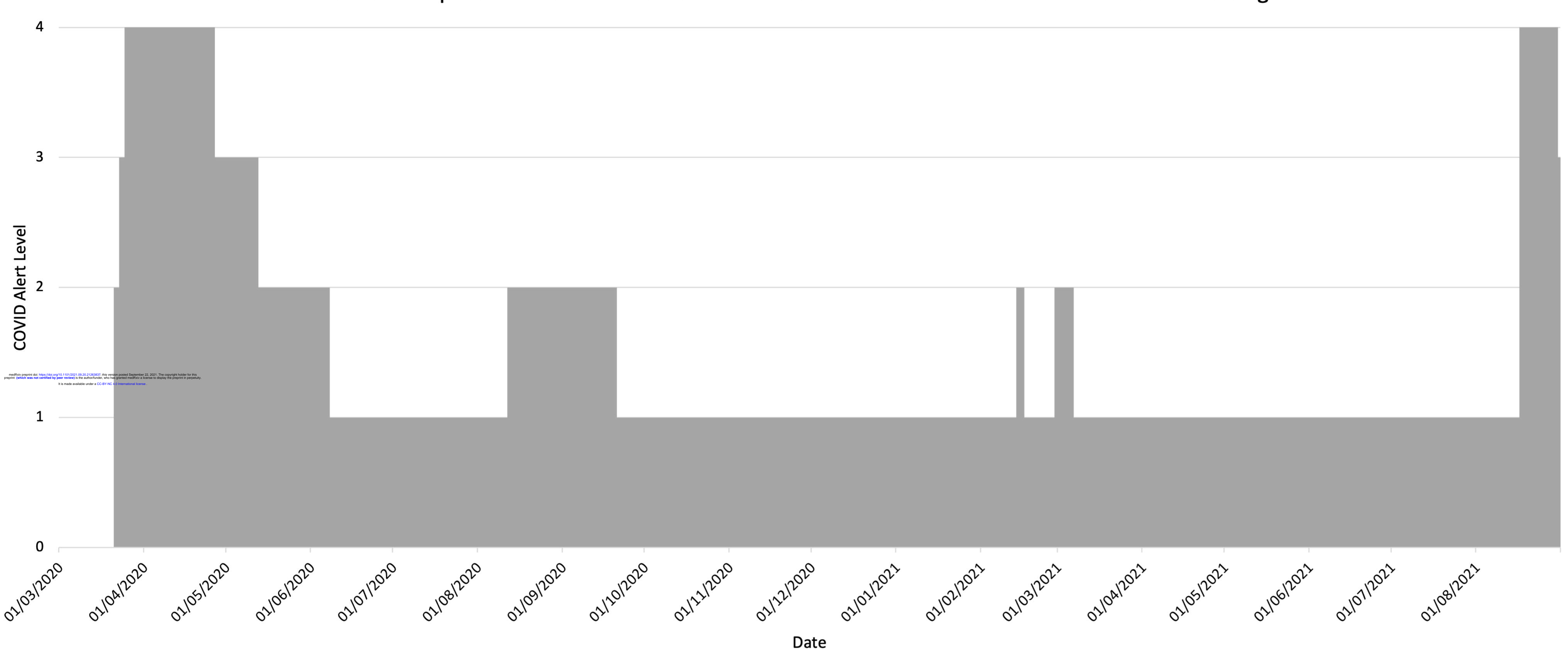




\begin{tabular}{|c|c|c|}
\hline Quote 1 & $\begin{array}{l}\text { My friendships and social life were the same before and after } \\
\text { lockdown. My social circle is small anyway so it is not } \\
\text { difficult to maintain. }\end{array}$ & $\begin{array}{l}\text { Māori woman, } \\
\quad 40 \mathrm{~s}\end{array}$ \\
\hline Quote 2 & Things returned to normal once we returned to level 1 . & $\begin{array}{l}\text { Pākehā woman, } \\
\text { 30s }\end{array}$ \\
\hline Quote 3 & $\begin{array}{l}\text { Thanks to the government keeping us safe, we've been able } \\
\text { to enjoy most of what we usually do. }\end{array}$ & $\begin{array}{l}\text { Pākehā woman, } \\
\text { 60s }\end{array}$ \\
\hline Quote 4 & $\begin{array}{l}\text { We are lucky to have an elimination strategy, so apart from } \\
\text { the initial lockdown itself very little had to change. }\end{array}$ & $\begin{array}{l}\text { Pākehā woman, } \\
\text { 30s }\end{array}$ \\
\hline Quote 5 & $\begin{array}{l}\text { Every time we are at level } 1 \text { or } 2 \text { then all of our social life } \\
\text { explodes again which is lovely - I'm willing to sacrifice here } \\
\text { and there in a level } 3 \text { or } 4 \text { in order for the huge gains we get } \\
\text { the rest of the time. We've been able to take holidays around } \\
\text { NZ, go to arts and sports events, I've been able to sing in my } \\
\text { symphonic choir with audiences of nearly } 3,000 \text {, go to big } \\
\text { birthday events, rugby, parties, and big work events. It's an } \\
\text { incredibly fortunate life so far. }\end{array}$ & $\begin{array}{l}\text { Pākehā woman, } \\
\text { 50s }\end{array}$ \\
\hline Quote 6 & Things & Pākehā man, 60s \\
\hline Quote 7 & $\begin{array}{l}\text { Having the freedom of choice to again visit friends and } \\
\text { family without any fear and go have a normal social life. }\end{array}$ & $\begin{array}{l}\text { Pākehā woman, } \\
\text { 70s }\end{array}$ \\
\hline Quote 8 & $\begin{array}{l}\text { In NZ everything was normal till this new lockdown so } \\
\text { normal life prevailed. In the UK everything was different - } \\
\text { unable to see my friends until the UK lockdown relaxed. } \\
\text { Even then I was frightened of putting folk in danger. Kept } \\
\text { wearing my mask }\end{array}$ & $\begin{array}{l}\text { Pākehā woman, } \\
60 \mathrm{~s}\end{array}$ \\
\hline Quote 9 & $\begin{array}{l}\text { By turning oft all media life can carry on without } \\
\text { and one sided rubbish }\end{array}$ & $\begin{array}{c}\text { Māori and } \\
\text { Pākehā man, 50s }\end{array}$ \\
\hline Quote 10 & $\begin{array}{l}\text { I am more mindful of sickness/illness and how my family } \\
\text { may impact the health of others and vice versa. I am much } \\
\text { more conscious about my movements and that of my family. }\end{array}$ & $\begin{array}{l}\text { Māori and } \\
\text { Pākehā woman, } \\
\text { 30s }\end{array}$ \\
\hline Quote 11 & $\begin{array}{l}\text { More or less the same but cognizant of public health } \\
\text { precautions - washing hands, etc }\end{array}$ & $\begin{array}{l}\text { Pākehā man, } \\
\quad 60 \mathrm{~s}\end{array}$ \\
\hline Quote 12 & $\begin{array}{l}\text { We don't have a raging social life with a young child and a } \\
\text { baby on the way. But we've been happy to go to theatres or } \\
\text { cinemas. I don't have any friends who are border workers } \\
\text { and don't get out too much in level } 2 \text { anyway. }\end{array}$ & $\begin{array}{c}\text { European } \\
\text { woman, 40s }\end{array}$ \\
\hline Quote 13 & $\begin{array}{l}\text { Although some of us have different opinions about the govt. } \\
\text { and their decisions re pandemic, our friendships are strong } \\
\text { and we can have robust discussions without getting personal. }\end{array}$ & $\begin{array}{l}\text { Pākehā woman, } \\
\text { 60s }\end{array}$ \\
\hline
\end{tabular}

Table 1. Returning to pre-pandemic normality. 
medRxiv preprint doi: https://doi.org/10.1101/2021.09.20.21263837; this version posted September 22, 2021. The copyright holder for this preprint (which was not certified by peer review) is the author/funder, who has granted medRxiv a license to display the preprint in perpetuity.

It is made available under a CC-BY-NC 4.0 International license .

\begin{tabular}{|c|c|c|}
\hline Quote 1 & $\begin{array}{l}\text { I have been going out as much as possible when not in lockdown } \\
\text { to make up for lost time }\end{array}$ & $\begin{array}{l}\text { Asian and Pākehā } \\
\text { woman, 20s }\end{array}$ \\
\hline Quote 2 & $\begin{array}{l}\text { I think we have embraced our friends and social life with much } \\
\text { more gusto, cos you just don't know when we'll be locked down } \\
\text { again. We've been doing quite a lot more domestic travelling and } \\
\text { local activities. Also trying to support local businesses. }\end{array}$ & $\begin{array}{c}\text { Australian } \\
\text { woman, 20s }\end{array}$ \\
\hline Quote 3 & $\begin{array}{l}\text { More social events as don't want to miss out because people could } \\
\text { die anytime. }\end{array}$ & $\begin{array}{l}\text { Pākehā woman, } \\
\text { 20s }\end{array}$ \\
\hline Quote 4 & I have made more effort to join in & Pākehā man, 60s \\
\hline Quote 5 & $\begin{array}{l}\text { I've built stronger friendships with my flatmates and been far more } \\
\text { willing to go out and do things. I think this has partially been in an } \\
\text { effort to make the most of the time we are not in lockdown. Prior } \\
\text { to the pandemic I often turned down social events to study. }\end{array}$ & $\begin{array}{l}\text { Pākehā woman, } \\
\text { 20s }\end{array}$ \\
\hline Quote 6 & $\begin{array}{l}\text { More appreciative of friends who can keep company through hard } \\
\text { things like lockdown. Some older friendships refreshed because of } \\
\text { time and drive to reconnect - rather than 'leaving it to another day'. }\end{array}$ & $\begin{array}{l}\text { Pākehā woman, } \\
50 \mathrm{~s}\end{array}$ \\
\hline Quote 7 & $\begin{array}{l}\text { Our neighbourhood formed closer friendships during previous } \\
\text { lockdown (socially distanced afternoon teas on the street), and we } \\
\text { have continued supportive closer relationships. }\end{array}$ & $\begin{array}{l}\text { Pākehā woman, } \\
60 \mathrm{~s}\end{array}$ \\
\hline Quote 8 & Got closer to most people. Am more honest about my emotions & $\begin{array}{l}\text { Pākehā woman, } \\
\quad 50 \text { s }\end{array}$ \\
\hline Quote 9 & $\begin{array}{l}\text { I think my social life has been better with more meaningful } \\
\text { relationships }\end{array}$ & $\begin{array}{l}\text { Pākehā woman, } \\
\quad 30 \text { s }\end{array}$ \\
\hline
\end{tabular}

Table 2. Becoming more social 


\begin{tabular}{|c|c|c|}
\hline Quote 1 & $\begin{array}{l}\text { Can't visit my best friend in Australia who has gone through a } \\
\text { really tough time. We've drifted apart a bit because of this. }\end{array}$ & $\begin{array}{l}\text { Māori and } \\
\text { Pākehā } \\
\text { woman, 30s }\end{array}$ \\
\hline Quote 2 & I seem to go out less to meet up with friends. & $\begin{array}{l}\text { European } \\
\text { woman, 50s }\end{array}$ \\
\hline Quote 3 & $\begin{array}{l}\text { It has been harder to reconnect with others. My } \\
\text { attendance/participation in usual activities (e.g. going to } \\
\text { church) has changed, I don't feel so well connected. I'm wary } \\
\text { of larger gatherings, not going to movies etc as much as before. }\end{array}$ & $\begin{array}{l}\text { Pākehā man, } \\
\quad 50 \mathrm{~s}\end{array}$ \\
\hline Quote 4 & $\begin{array}{l}\text { I'm less social now and have } \mathrm{t} \\
\text { friendships and relationships }\end{array}$ & $\begin{array}{l}\text { Pākehā } \\
\text { woman, } 50 \mathrm{~s}\end{array}$ \\
\hline Quote 5 & $\begin{array}{l}\text { I am spending more quality time with fewer people. I'm } \\
\text { mindful of my world having shrunk quite considerably since } \\
\text { COVID. }\end{array}$ & $\begin{array}{l}\text { European } \\
\text { woman, } 40 \mathrm{~s}\end{array}$ \\
\hline Quote 6 & $\begin{array}{l}\text { My husband has become reluctant to socialise around } \\
\text { strangers. He doesn't trust them to keep him safe. Therefore } \\
\text { we do not go out very much. Friends are more careful about } \\
\text { visiting if they have a cold etc. }\end{array}$ & $\begin{array}{l}\text { Pākehā } \\
\text { woman, 70s }\end{array}$ \\
\hline Quote 7 & $\begin{array}{l}\text { I keep away from large groups as I would hate to spread covid } \\
\text { to my tiny community. }\end{array}$ & $\begin{array}{l}\text { Pacific and } \\
\text { Pākehā } \\
\text { woman, 40s }\end{array}$ \\
\hline Quote 8 & $\begin{array}{l}\text { I'm way less social than I used to be. I feel anxious and stressed } \\
\text { all the time, and then staying at home leaves me depressed, } \\
\text { which makes me less likely to want to socialise. I haven't seen } \\
\text { many friends at all this year. }\end{array}$ & $\begin{array}{l}\text { Pākehā man, } \\
\text { 30s }\end{array}$ \\
\hline Quote 9 & $\begin{array}{l}\text { It's been very hard to maintain social connections because } \\
\text { events keep getting cancelled. I live by myself, and I now } \\
\text { spend a lot of time by myself... }\end{array}$ & $\begin{array}{c}\text { Pākehā } \\
\text { woman, 30s }\end{array}$ \\
\hline Quote 10 & $\begin{array}{l}\text { Minimal due to lockdown fatigue i.e. the effect of lockdown } \\
\text { have drained all my energy and I don't have the energy to } \\
\text { socialise. Also planning is very difficult. }\end{array}$ & $\begin{array}{l}\text { Pākehā } \\
\text { woman, 50s }\end{array}$ \\
\hline Quote 11 & $\begin{array}{l}\text { I go out less socially - not from fear of COVID just from habit. } \\
\text { More time spent at home since last lockdown. }\end{array}$ & $\begin{array}{l}\text { Pākehā non- } \\
\text { binary person, } \\
30 \mathrm{~s}\end{array}$ \\
\hline Quote 12 & $\begin{array}{l}\text { I've lost } 2 \text { friends of more than } 20 \text { years standing. We no longer } \\
\text { speak as we reacted to lockdown in very different ways. One } \\
\text { was a rulebreaker and I could not cope with this lack of } \\
\text { morality. The other became very stressed and turned very } \\
\text { nasty, so I had to back off and have not been keen to go back. }\end{array}$ & $\begin{array}{c}\text { Pākehā } \\
\text { woman, 50s }\end{array}$ \\
\hline Quote 13 & $\begin{array}{l}\text { A lot of people kind of withdrew into their family life during } \\
\text { lockdown and not all of them have been as social afterwards. }\end{array}$ & $\begin{array}{l}\text { Māori and } \\
\text { Pākehā man, } \\
\text { 30s }\end{array}$ \\
\hline
\end{tabular}




\begin{tabular}{|c|c|c|}
\hline Quote 14 & $\begin{array}{l}\text { I have agreed to end a friendship of long standing - partly due } \\
\text { to a growing divide in how we see government, societal, media } \\
\text { and our individual responses to the pandemic. The friend I am } \\
\text { thinking of has tried to share conspiracy theories with me, and I } \\
\text { have tried to stay alongside and understand why she is attracted } \\
\text { to that thinking, but it proved too much for us both. }\end{array}$ & $\begin{array}{l}\text { Māori and } \\
\text { Pākehā } \\
\text { woman, 50s }\end{array}$ \\
\hline Quote 15 & $\begin{array}{l}\text { I see people less often than before, even talk less often as } \\
\text { friends and family my age stay home more and have less to talk } \\
\text { about. }\end{array}$ & $\begin{array}{c}\text { Pākehā } \\
\text { woman, 60s }\end{array}$ \\
\hline Quote 16 & $\begin{array}{l}\text { I have tended to focus on fewer more important relationships, } \\
\text { and not so much the 'lite' friendships. }\end{array}$ & $\begin{array}{c}\text { Pākehā } \\
\text { woman, 30s }\end{array}$ \\
\hline Quote 17 & $\begin{array}{l}\text { A few friends fell away \& several more grew closer. } \\
\text { Socialising has been smaller, more often one-on-one } \& \text { tend to } \\
\text { talk more deeply }\end{array}$ & $\begin{array}{l}\text { Pākehā } \\
\text { woman, 30s }\end{array}$ \\
\hline Quote 18 & $\begin{array}{l}\text { I indulge my introvert side more. I no longer feel I 'should' } \\
\text { make an effort to eg go out into the city or attend events if I } \\
\text { don't really feel like it. It's fine to stay home and stay safe, and } \\
\text { use less petrol etc too. }\end{array}$ & $\begin{array}{c}\text { European } \\
\text { woman, } 60 \mathrm{~s}\end{array}$ \\
\hline Quote 19 & $\begin{array}{l}\text { As I have ME/CFS I am already socially isolated and the } \\
\text { pandemic has exacerbated this and I feel like nobody cares } \\
\text { about me. }\end{array}$ & $\begin{array}{c}\text { Pākehā } \\
\text { woman, 40s }\end{array}$ \\
\hline Quote 20 & $\begin{array}{l}\text { Definitely feel flatter, poorer mental health, just less to look } \\
\text { forward to and a sense that anything I plan could be cancelled, } \\
\text { plus friendships more fragmented }\end{array}$ & $\begin{array}{c}\text { Pākehā } \\
\text { woman, 20s }\end{array}$ \\
\hline
\end{tabular}




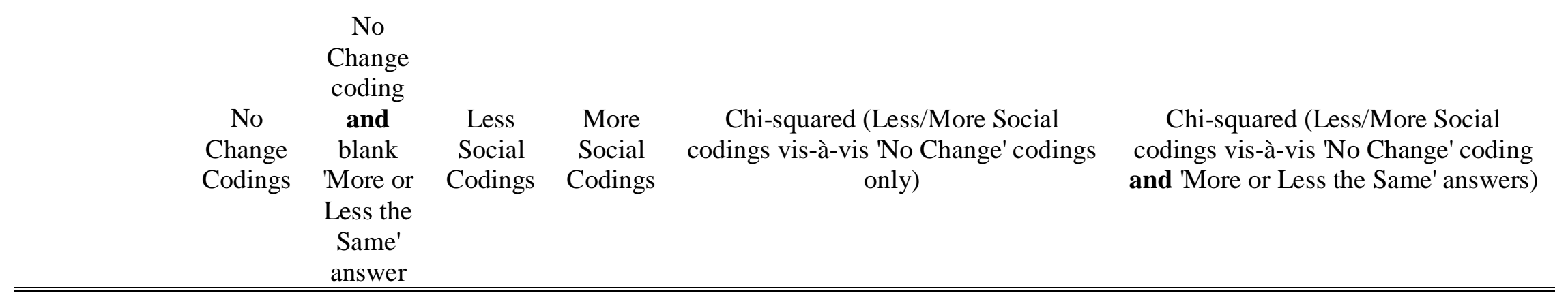

\section{Gender}

Woman

Man

$\begin{array}{ccc}100 & 400 & 203 \\ 26 & 101 & 32 \\ 2 & 7 & 8 \\ 1 & 5 & 4\end{array}$

Non-binary

(Prefer not to

say / blank)

4
78

7

0

$X^{2}(2, \mathrm{~N}=446)=6.534 ; \mathrm{p}=0.036^{*}$
Including non-binary respondents:
$X^{2}(4, \mathrm{~N}=457)=8.465 ; \mathrm{p}=0.076 \quad X^{2}(4, \mathrm{~N}=837)=13.578 ; \mathrm{p}=0.009 * *$
Excluding non-binary respondents (due to low cell sizes):

Including non-binary respondents:
$X^{2}(4, \mathrm{~N}=457)=8.465 ; \mathrm{p}=0.076 \quad X^{2}(4, \mathrm{~N}=837)=13.578 ; \mathrm{p}=0.009 * *$
Excluding non-binary respondents (due to low cell sizes):

$$
X^{2}(2, \mathrm{~N}=821)=10.052 ; \mathrm{p}=0.007 * *
$$

Age

$18-34$

$35-50$

$50-64$

$65+$

(Prefer not to

say / blank)

$\begin{array}{cccc}31 & 93 & 38 & 24 \\ 32 & 142 & 66 & 23 \\ 43 & 193 & 80 & 24 \\ 23 & 77 & 59 & 11 \\ 0 & 8 & 4 & 4\end{array}$

Health Status: Do you have any underlying conditions that may affect your vulnerability to COVID-19? 


\begin{tabular}{|c|c|c|c|c|c|c|}
\hline Yes & 31 & 144 & 107 & 31 & Including 'don't know's: & \\
\hline No & 91 & 340 & 122 & 52 & $X^{2}(4, \mathrm{~N}=457)=16.040 ; \mathrm{p}=0.003^{* *}$ & $X^{2}(4, \mathrm{~N}=838)=20.350 ; \mathrm{p}=0.0004$ \\
\hline Don't know & 6 & 25 & 14 & 3 & Excluding 'don't know's: & \\
\hline $\begin{array}{l}\text { (Prefer not to } \\
\text { say / blank) }\end{array}$ & 1 & 4 & 4 & 0 & $X^{2}(2, \mathrm{~N}=434)=15.318 ; \mathrm{p}=0.0005^{* *}$ & $X^{2}(2, \mathrm{~N}=796)=19.725 ; \mathrm{p}=0.0000$ \\
\hline \multicolumn{7}{|l|}{$\begin{array}{l}\text { Household } \\
\text { size }\end{array}$} \\
\hline 1 & 27 & 102 & 49 & 19 & $X^{2}(8, \mathrm{~N}=461)=2.249 ; \mathrm{p}=0.972$ & $X^{2}(8, \mathrm{~N}=845)=5.138 ; \mathrm{p}=0.743$ \\
\hline 2 & 41 & 173 & 88 & 27 & & \\
\hline 3 & 23 & 102 & 44 & 18 & & \\
\hline 4 & 23 & 91 & 34 & 13 & & \\
\hline 5 or more & 15 & 45 & 31 & 9 & & \\
\hline $\begin{array}{l}\text { (Prefer not to } \\
\text { say / blank) }\end{array}$ & 0 & 0 & 1 & 0 & & \\
\hline \multicolumn{7}{|l|}{$\begin{array}{l}\text { Education } \\
\text { status } \\
\text { No }\end{array}$} \\
\hline $\begin{array}{l}\text { qualifications } \\
\text { / high school } \\
\text { only }\end{array}$ & 22 & 90 & 29 & 12 & $X^{2}(4, \mathrm{~N}=460)=6.223 ; \mathrm{p}=0.183$ & $X^{2}(4, \mathrm{~N}=841)=6.233 ; \mathrm{p}=0.182$ \\
\hline $\begin{array}{l}\text { Undergraduat } \\
\text { e degree / } \\
\text { professional } \\
\text { qualification }\end{array}$ & 70 & 248 & 111 & 43 & & \\
\hline $\begin{array}{l}\text { Postgraduate } \\
\text { degree }\end{array}$ & 37 & 172 & 99 & 31 & & \\
\hline (Prefer not to & 0 & 3 & 2 & 0 & & \\
\hline
\end{tabular}


say / blank)

\section{Ethnicity}

New Zealand

European /

104

459

215

85

Pākehā

White Other

Māori

Pacific

Asian

Other

(Prefer not to

say / blank)

\section{Concatenate}

\section{d ethnicity:}

White only

Person of

Colour

99

99

452

$$
212
$$

84

$$
X^{2}(2, \mathrm{~N}=461)=2.197 ; \mathrm{p}=0.333
$$$$
X^{2}(2, \mathrm{~N}=860)=0.219 ; \mathrm{p}=0.896
$$

Māori

68

33

11

Non-Māori

$12 \quad 34$

$$
22
$$

$109 \quad 486$

486

223

3

$$
X^{2}(2, \mathrm{~N}=461)=3.938 ; \mathrm{p}=0.140
$$$$
X^{2}(2, \mathrm{~N}=860)=3.844 ; \mathrm{p}=0.146
$$

\section{Māori and}

Pacific

17

\section{Neither}

Māori nor

Pacific 